\title{
Differing Pulmonary Structural Abnormalities Detected on Pulmonary MR Imaging in Cystic Fibrosis Patients with Varying Pancreatic Function
}

\author{
Detektion von unterschiedlichen strukturellen \\ Lungengerüstveränderungen mittels pulmonalem MRT bei Patienten \\ mit zystischer Fibrose und unterschiedlicher Pankreasfunktion
}

Authors

Mareen Sarah Kraus ${ }^{1}$, Matthias Teufel ${ }^{2}$, Michael Esser ${ }^{1}$, Lena Sophie Kiefer ${ }^{1}$, Sabrina Fleischer ${ }^{1}$, Ute Graepler-Mainka ${ }^{1}$, Andreas Hector ${ }^{3}$, Ilias Tsiflikas ${ }^{1}$, Jürgen F. Schaefer ${ }^{1}$

Affiliations

1 Radiology, Eberhard-Karls-University Tübingen, Tübingen, Germany

2 Community practice for Diagnostic Radiology and Nuclear Medicine, Klinikum Schwäbisch Gmünd, Mutlangen, Germany

3 Paediatrics, Eberhard-Karls-University Tübingen, Tübingen, Germany

Key words

pancreas, thorax, MR-functional imaging, atelectasis, genetic defects, MR imaging

received 30.07.2019

accepted 16.12.2019

Bibliography

DOI https://doi.org/10.1055/a-1088-3537

Published online: 6.2.2020

Fortschr Röntgenstr 2020; 192: 567-575

(c) Georg Thieme Verlag KG, Stuttgart · New York ISSN 1438-9029

Correspondence

Dr. Mareen Sarah Kraus

Radiology, Eberhard-Karls-University Tübingen,

Hoppe-Seyler-Str. 3, 72076 Tübingen, Germany

Tel.: ++49/70 71/2986677

mareen.kraus@med.uni-tuebingen.de

\section{ZUSAMMENFASSUNG}

Ziel Die Multisystemerkrankung zystische Fibrose (CF) zeigt phänotypisch eine große Symptomvarianz, wobei Genotypen mit suffizienter Pankreasfunktion (PS) eine mildere Lungenbeeinträchtigung aufzuweisen scheinen im Vergleich zu pankreasinsuffizienten (PI) CF-Patienten. Ziel dieser Studie war die Evaluation von strukturellen Lungengerüstveränderungen (SLD) bei CF-Patienten mit unterschiedlicher Pankreasfunktion mittels pulmonalem MRT-Score (MR-CF-Score).
Material und Methoden 20 CF-Patienten wurden in diese retrospektive monozentrische Studie eingeschlossen: 10 PSCF-Patienten (mittleres Alter 12,5 Jahre; 6 männlich; BMI $17,4 \mathrm{~kg} / \mathrm{m}^{2} ; \mathrm{FeV}_{1} 102 \%$ ) wurden nach Geschlecht, Alter und Lungenfunktion mit 10 PI-Patienten gepaart. Erfahrene Radiologen beurteilten die strukturellen Lungenveränderungen in jedem Lungenlappen mittels semi-quantitativem MR-CFScore: Dieser beinhaltet Bronchiektasien/peribronchiale Wandverdickung, Mukusverlegung, zentrilobuläre Opazität, Konsolidierung, Sakkulation und Überblähung/Air Trapping. Der Score sowie die kategorischen Werte wurden mit dem Pankreasstatus korreliert.

Ergebnisse CF-PS-Patienten zeigten einen signifikant niedrigeren MR-CF-Gesamtscore $(p=0,024)$ und damit mildere Lungengerüstveränderungen. Die größten kategorischen Unterschiede waren bezüglich Bronchiektasien $(p=0,0042)$ und Überblähung ( $p=0,0304)$ zu beobachten. SLD waren insbesondere in den Lungenoberfeldern am deutlichsten, jedoch zeigten sich signifikante Unterschiede in Bezug auf die Pankreasfunktion in sowohl den Lungenober- als auch -unterfeldern $(p=0,0247$ und $p=0,0196)$.

Schlussfolgerung Unsere Ergebnisse zeigen signifikante Unterschiede bezüglich SLD und Pankreasstatus bei CF-Patienten mit identischen Lungenfunktionswerten. Pankreasinsuffiziente Patienten zeigten hierbei deutlich schwerere Lungengerüstveränderungen im MRT, insbesondere Bronchiektasien und Überblähung.

\section{Kernaussagen:}

- Pulmonales MRT ermöglicht eine morphologische und funktionelle Diagnostik ohne Einsatz ionisierender Strahlung.

- CF-Patienten mit insuffizienter Pankreasfunktion zeigen ausgeprägtere strukturelle Lungengerüstveränderungen im Vergleich zu pankreassuffizienten Patienten bei gleicher Lungenfunktion.

- Bronchiektasien und Überblähung sind die häufigsten strukturellen Lungengerüstveränderungen mit Betonung der Lungenoberfelder. 


\section{ABSTRACT}

Purpose In cystic fibrosis (CF) the phenotypic expression of complaints varies widely. Genotypes with sufficient pancreatic function (PS) exhibit milder lung disease compared to CF patients with insufficient pancreatic function (PI). The purpose of this study was to evaluate structural lung disease (SLD) in CF patients with differing pancreatic status but similar results on pulmonary function testing using a pulmonary magnetic resonance imaging score (MR-CF score).

Materials and Methods In this retrospective study, 20 patients in our single-center CF database were included: 10 with PS (mean age 12.5 years; six male; BMI $17.4 \mathrm{~kg} / \mathrm{m}^{2} ; \mathrm{FeV}_{1} 102 \%$ ) were matched by gender, age and lung function with $10 \mathrm{PI}$ patients. Experienced observers semi-quantitatively assessed SLD for each lung lobe. The established MR-CF score measures the extent and the severity of bronchiectasis and bronchial wall thickening, mucus plugging, centrilobular opacity, consolidation, sacculation, and air trapping. The total score and subscore values were compared to the pancreatic status.

Results Patients with CF-PS had overall statistically significant lower MR-CF scores $(p=0.024)$, and therefore milder SLD, compared to CF-PI. The differences were most significant for bronchiectasis $(p=0.0042)$ and air trapping $(p=0.0304)$. SLD was more severe in the upper lobes in all patients. However, differences between CF-PS and CF-PI patients were present in both the upper and lower lung areas $(p=0.0247$ and $p=0.0196$, respectively)

Conclusion Our results demonstrated that CF patients with impaired pancreatic function show more severe lung pathology detected by MRI, especially bronchiectasis and air trapping.

\section{Key points:}

- Pulmonary MRI offers morphological and functional details without using ionizing radiation

- CF patients with pancreatic insufficiency show more severe pulmonary structural impairment

- Bronchiectasis and air trapping are the most common structural lung changes with predominance in the upper lung lobes.

\section{Citation Format}

- Kraus MS, Teufel M, Esser M et al. Differing Pulmonary Structural Abnormalities Detected on Pulmonary MR Imaging in Cystic Fibrosis Patients with Varying Pancreatic Function. Fortschr Röntgenstr 2020; 192: 567-575

\section{Introduction}

Among Caucasians, cystic fibrosis (CF) is one of the most common life-limiting autosomal-recessive genetic disorders and is a consequence of mutations to the cystic fibrosis transmembrane conductance regulator gene [1]. Dysfunctional chloride channels result in abnormally thickened, viscous exocrine secretions of the respiratory, digestive and reproductive system. The detection rate of $C F$ is inconsistent across the world; in Europe the incidence is $1 /$ 2000-3000 births and in the United States 1/3500 births [2].

The phenotypic expression and the severity vary widely with pulmonary complications being the most serious and causing mortality in more than $90 \%$ of CF patients [3, 4]. Thickened mucus and decreased mucocilliary clearance cause prolonged pulmonary infections, more pronounced inflammation and the development of irreversible structural changes.

The CFTR protein is highly expressed in the pancreatic ductal epithelia. Therefore, impairment of the pancreatic gland is seen in most CF patients (85\%). It ranges from mucus accumulation in the small ducts to atrophy following total ductal obstruction. According to the Quinton hypothesis, a defect in the bicarbonate transport of the pancreas is the primary defect in CF with a net reduced volume of alkaline fluid and hyperconcentration of macromolecules secreted by the acinar cells [5]. Before newborn CF screening was introduced, patients with sufficient pancreatic function (PS) were diagnosed with CF much later in life since these CF patients sustain milder structural lung disease (SLD) compared to CF patients with impaired or absent pancreatic enzymes, i. e. insufficient pancreatic function (PI) [6, 7].

Pulmonary function tests have been shown to be falsely reassuring and, especially in early disease stages, normal, despite structural alterations being already present on imaging [8-10]. With regard to pulmonary imaging, $\mathrm{CT}$ examination of the chest is still the gold standard in CF [11-13]. However, particularly in children or young adults and with recurrent imaging in chronic pulmonary disease, the accumulated radiation dose is most relevant. In university hospitals or specialized centers, pulmonary MRI is increasingly used and has proven its feasibility for disease monitoring and morphological pulmonary damage assessment [9]. Thus, an accurate prediction of exacerbation and therapy adjustment can be achieved. This radiation-free technique also offers an indication of pulmonary function, such as trapped air and, during multiphase examinations, pulmonary MRI can highlight air trapping, which is a reversible CF sign [13, 14].

The objective of this study was to evaluate the differences in the severity, type and distribution of pulmonary changes of CF in patients with differing pancreatic status and to assess any correlation therewith using a standardized pulmonary MRI protocol.

\section{Material and Methods}

The institutional review board approved this retrospective study. MRI was clinically indicated thus the need to obtain further written informed consent was waived. No additional or external funding was received.

\section{Study population}

We identified patients with sufficient pancreatic function in our single-center hospital's CF patient register database between January 2014 and March 2017, which was ultimately almost 130 patients. The inclusion criteria were the following: Patient with diag- 

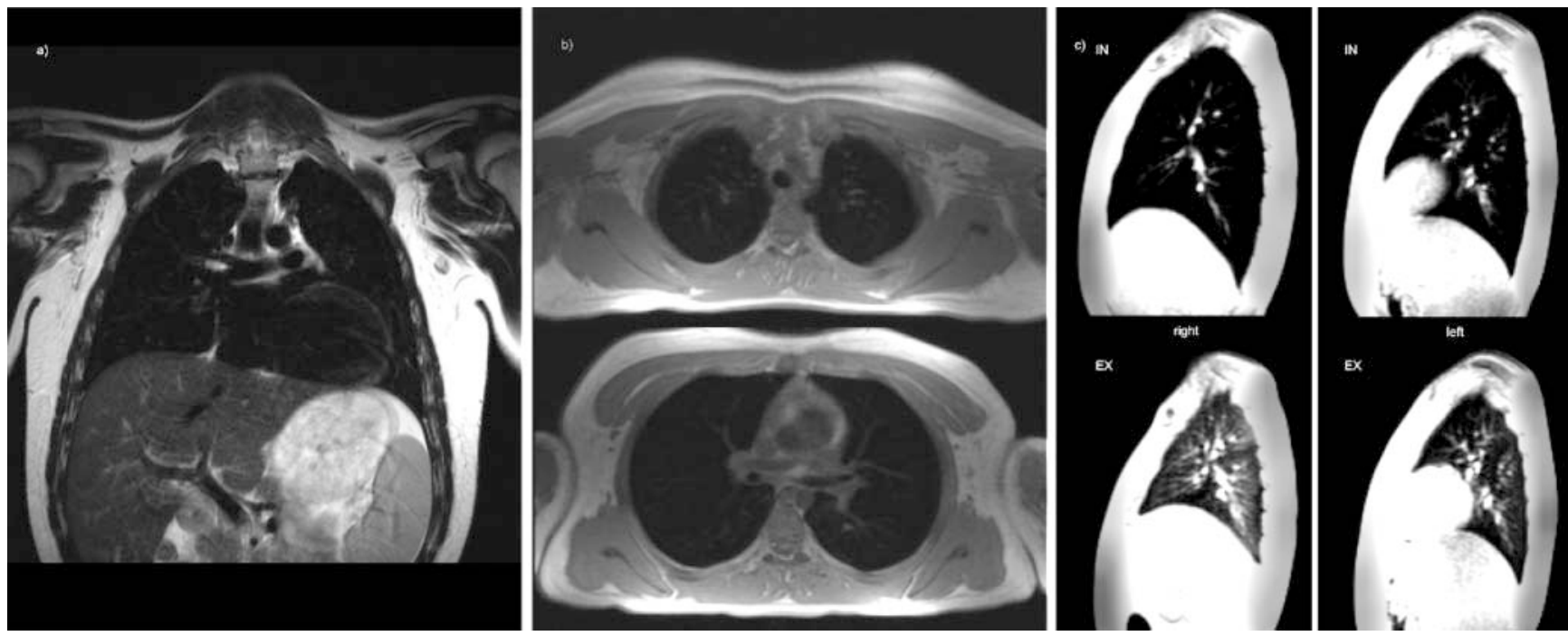

- Fig. 1 The in-house standard CF protocol consisting of two morphological sequences (from right to left): a coronal fs T2w turbo spin echo sequence with ECG-triggering and respiratory gating, $\mathbf{b}$ transverse $3 \mathrm{D}$ gradient echo sequence with breath-hold (9-12 s). Additionally for functional assessment: c sagittal proton-density-weighted 2 D GRE sequences of each lung lobe in submaximal inspiration (IN) and expiration (EX).

- Abb. 1 Institutionelles Standard-CF-Untersuchungsprotokoll bestehend aus 2 morphologischen Sequenzen (rechts nach links): a koronale fs-T2w-Turbo-Spin-Echo-Sequenz mit EKG- und Atemtriggerung, b transversale 3D-Gradientenecho-Sequenz in Atemstopp (9-12s), zusätzliche Sequenz zur funktionellen Beurteilung mittels c sagittaler Protonendichte-gewichteten 2D-Gradientenecho-Sequenz in submaximaler In- (IN) und Exspiration (EX).

nosed CF (through positive sweat test or attested CFTR gene mutation) who received clinically indicated pulmonary MRI using the university's standard CF MRI protocol and pulmonary function testing with a whole-body plethysmography $\left(\mathrm{FEV}_{1}\right)$ on the same day.

Pancreatic function quantified by the exocrine secretion was determined by fecal elastase- 1 test, serum trypsinogen and fecal chymotrypsin.

The exclusion criteria were missing/incorrect pancreatic or pulmonary function tests and our hospital's general exclusion criteria for MRI such as metallic implants.

We found $11 \mathrm{CF}$ patients to be PS with MR imaging between 01/2014 and 03/2017, and there were 115 PI patients. Subsequently these patients were matched on a per-group basis to gender, age, BMI, lung function parameters and MR imaging (scanner and within a 3-month time point to provide the same pulmonary sequence protocols) to the remaining CF-PI cohort. One CF-PS patient's parameters ( $\mathrm{FEV}_{1}$ and $\mathrm{MRI}$ ) could not be matched to a CF-PI patient. Therefore, the total sample size was 20, i.e. 6 male and 4 female matched pairs.

\section{Data acquisition}

All images were acquired on a 1.5 Tesla MR scanner (Magnetom Aera/Avanto fit; Siemens Medical Systems, Germany) using a 6channel body array coil with respiratory gating. MRI was performed with the patient in a supine position. The university's standard CF MRI protocol is comprised of morphological (a \& b) and functional (c) imaging with the following sequences: a) a coronal T2w turbo spin echo (TSE) sequence (TR $4000 \mathrm{~ms}$, TE $97 \mathrm{~ms}$, flip angle $150^{\circ}$, voxel $1.6 \times 1.6 \times 3 \mathrm{~mm}^{3}$, overlapping blocks 1 , average 3 , acquisition time 5-10 mins).

b) a transverse $3 \mathrm{D}$ gradient echo (GRE) sequence (repetition time (TR) $2.84 \mathrm{~ms}$, echo time (TE) $0.87 \mathrm{~ms}$, flip angle $5^{\circ}$, voxel $1.7 \times 1.4 \times 3 \mathrm{~mm}^{3}$, overlapping blocks 3 , average 1 , acquisition time $9-12 \mathrm{~s}$ per block)

c) a sagittal proton-density-weighted $2 \mathrm{D}$ GRE sequence (TR $2.5 \mathrm{~ms}$, TE $0.8 \mathrm{~ms}$, flip angle $5^{\circ}$, voxel $2.0 \times 1.6 \times 15 \mathrm{~mm}^{3}$, overlapping blocks 4 , averages 6 , acquisition time $8 \mathrm{~s}$ per block) in submaximal inspiration and expiration.

The total CF MRI protocol acquisition time ranged between 15 and 20 minutes. The sequence parameters of our institutional CF MRI protocol have been consistent for the last 10 years and have been previously published [14]. An example is given in \ Fig. 1 .

\section{Image analysis}

MR images were analyzed in random order in a consensus reading by 2 radiologists: J.S. an expert in pediatric radiology and chest imaging with more than 25 years of experience; M.K. with four years of experience in medical imaging. The radiologists were blinded to patient characteristics, pancreatic function, pulmonary function testing and the original imaging reports. The readers could scroll through the whole stack of images and adjust the window settings and orientation.

Pulmonary impairment was semi-quantitatively assessed using the established, in-house-developed CF scoring system "MR-CF score". The score evaluates the following: (1) bronchiectasis and peribronchial wall thickening (assessed as one category due to lim- 
- Table 1 Definition of the MR-CF scoring categories and exemplary structural evaluation sheet.

- Tab.1 Definition der kategorischen Parameter des MR-CF-Scores und beispielhaft ein strukturelles Befundungsdokument.

\begin{tabular}{|c|c|c|c|c|c|c|c|}
\hline \multirow{3}{*}{ category } & \multirow{3}{*}{ definition } & \multicolumn{6}{|l|}{ score } \\
\hline & & \multicolumn{6}{|c|}{$0=$ not present, $1=$ visible, $2=$ marked } \\
\hline & & RUL & ML & RLL & LUL & LS & LLL \\
\hline bronchiectasis/peribronchial wall thickening & $\begin{array}{l}\text { cylindrical or varicose dilatation with or } \\
\text { without bronchial wall thickening }\end{array}$ & & & & & & \\
\hline mucus plugging & $\begin{array}{l}\text { hyperintense filling of the central or } \\
\text { peripheral dilated bronchi }\end{array}$ & & & & & & \\
\hline centrilobular opacities & $\begin{array}{l}\text { centrilobular increased signal including } \\
\text { nodules, tree-in-bud pattern }\end{array}$ & & & & & & \\
\hline sacculations & $\begin{array}{l}\text { air-filled cystic structure with or without } \\
\text { fluid level }\end{array}$ & & & & & & \\
\hline consolidations & $\begin{array}{l}\text { hyperintense area of lung parenchyma } \\
\text { obscuring vessels with or without air }\end{array}$ & & & & & & \\
\hline air trapping & $\begin{array}{l}\text { in expiration geographic or diffuse areas } \\
\text { of low signal that is obviously not above } \\
\text { level of inspiration }\end{array}$ & & & & & & \\
\hline
\end{tabular}

ited spatial resolution of MRI), (2) mucus plugging, (3) centrilobular opacity, (4) consolidation, (5) sacculation, and (6) air trapping. The latter, as a functional parameter, is assessed using the non-static, sagittal 2D PD GRE sequences in submaximal inspiration and expiration. A 2-point Likert scale is used to quantify the changes of each category with a score of 0 representing no pathologies, a score of 1 meaning "diffusely marked" pathologies and a score of 2 indicating "clearly marked" pathologies on imaging. Pulmonary findings of each category were rated per lobe (i. e., 6 segments: right upper lobe, right middle lobe, right lower lobe, left upper lobe, the left lower lobe and the lingual segment). Lastly, the morphologic structural and functional abnormalities were added up to form a total MR-CF score with a possible maximum of 72 points, as previously published [15] and demonstrated in $>$ Table 1.

The distribution of lung pathology was separately assessed. Thereby, the upper lung areas were defined as upper lung lobes as well as the lingula and the middle lobe.

\section{Statistical Analyses}

SAS jmp ${ }^{\circledR}$ statistic software (SAS jmp ${ }^{\circledR} 14$; SAS Institute, Cary, NC, United States) was used for statistical analysis. Quantitative continuous variables were expressed as mean \pm standard deviation (SD). The severity and distribution of pulmonary disease were compared using nonparametric Kruskal-Wallis tests. The intraclass correlation coefficient (ICC) was used for the overall score reproducibility and Cohen's kappa correlation coefficient for the item scoring on a second consensus reading 2 months after the initial readings. Later, individual readings were performed and the inter-reader correlation was calculated using the Cohen's kappa correlation coefficient. A P-value smaller than 0.05 was considered of statistical significance.

\section{Results}

\section{Population characteristics}

Ten of the eleven identified PS patients of the department's CF population had an available MRI examination and were matched with $\mathrm{PI}-\mathrm{CF}$ patients. $\mathrm{FeV}_{1}$ at the time of MRI was quite high for both subgroups and within a $1 \%$ range, see $\$ Table 2 . The most common CFTR mutation was delta F508 for both groups and was seen slightly more often in PI than in PS patients. Hereby in 5/6 PI patients this was a homozygous inheritance, whereas delta F 508 mutations in PS patients were solely of heterozygous inheritance. The number of chronic bacterial colonizations, primarily of Staphylococcus aureus, was similar for both groups. However, mixed bacterial colonization was mostly seen in the PI patient cohort.

Clinical data of all included patients are summarized in $>$ Table 2 .

\section{Pulmonary Pathology Categories and MR-CF-Score}

In all 20 patients, the acquired MRI scan was of good diagnostic image quality and no scans were excluded due to poor image quality, e. g. motion artifacts or incomplete sequence acquisition. Bronchiectasis/peribronchial wall thickening was the most common SLD finding seen on MRI (14/20 patients), followed by air trapping (12/20). Consolidation was noted in $8 / 20$, mucus plugging in 6/20 and centrilobular opacities in 4/20. Sacculation was not seen on any of the images, see $>$ Fig. 2 .

Correlation of the MR-CF score in relation to the pancreatic status of the CF patients showed that PS-CF had a significantly lower overall total MR-CF score (median 3 (range 0-4.25); $\mathrm{p}=0.024$ ) compared to PI-CF (median 5.5 (range 3.75-14.5). The largest differences in lung abnormalities between PS-CF and PI-CF, and therefore the highest scores, were in bronchiectasis/bronchial 
- Table 2 Demographics of study patients including age at MRI examination, gender, BMI, functional lung parameters FeV ${ }_{1}$ and chronic bacterial colonization.

- Tab.2 Charakteristiken der Studienteilnehmer mit Alter bei der MRT-Untersuchung, Geschlecht, BMI, Parameter der Lungenfunktion (FeV ${ }_{1}$ ) und chronisch bakterielle pulmonale Besiedlung.

\begin{tabular}{|c|c|c|c|}
\hline & $\begin{array}{l}\text { total } \\
(n=20)\end{array}$ & $\begin{array}{l}\text { pancreatic sufficiency } \\
(n=10)\end{array}$ & $\begin{array}{l}\text { pancreatic insufficiency } \\
(n=10)\end{array}$ \\
\hline age $^{1}$ in years (mean $\pm S D$ ) & $12.22 \pm 4.07$ & $12.5 \pm 4.0$ & $12.0 \pm 4.2$ \\
\hline male/female sex & $12 / 8$ & $6 / 4$ & $6 / 4$ \\
\hline $\operatorname{BMI}\left(\mathrm{kg} / \mathrm{m}^{2}\right)^{1}$ & $17.67 \pm 3.0$ & $17.4 \pm 3.0$ & $17.9 \pm 3.2$ \\
\hline $\mathrm{FeV}_{1}$ (percentage of predicted; mean $\left.\pm \mathrm{SD}\right)^{1}$ & $98.2 \pm 11.4$ & $98.7 \pm 10.3$ & $97.7 \pm 12.9$ \\
\hline mean $\mathrm{FeV}_{1}$ (percentage of predicted; mean $\left.\pm \mathrm{SD}\right)^{2}$ & $102.3 \pm 10.0$ & $102.16 \pm 11.3$ & $102.48 \pm 8.9$ \\
\hline CF diagnosis within the first year of life & 11 & 5 & 6 \\
\hline CFTR delta F508 Mutation & 12 & 6 & 4 \\
\hline chronic bacterial colonization ${ }^{1}$ & 15 & 8 & 7 \\
\hline sole Pseudomonas aeruginosa colonization ${ }^{1}$ & 2 & 0 & 2 \\
\hline sole Staphylococcus aureus colonization ${ }^{1}$ & 10 & 7 & 3 \\
\hline $\begin{array}{l}1 \text { at time point of MRI. } \\
\text { zum Zeitpunkt des MRTs. } \\
2 \text { mean value } 2 \text { years prior to MRI. } \\
\text { Mittelwert im Zeitraum von } 2 \text { Jahren vor MRT. }\end{array}$ & & & \\
\hline
\end{tabular}

wall thickening $(p=0.0042)$ and functional impairment air trapping $(p=0.034)$. The results are detailed in $\downarrow$ Table 3 , $>$ Fig. 3 .

When having a closer look at the distribution of SLD, the upper lung lobes were more severely affected than the lower lung lobes: generally, there was a significant difference $(p<0.0001)$ in the whole cohort with SLD predominance in the upper lobes with $64 \mathrm{MR}$-CF score points in contrast to the lower lobes with a total of 35 points. Concordantly there was a significant difference in the MRI finding between the two pancreatic function subgroups for both the upper and lower lobes ( $p=0.0247$ and 0.0196 , respectively).

However, there was no predominantly affected segmental lung area when considering the differences in pancreatic function.

The intra-reader correlation regarding the overall MR-CF score was excellent (ICC $=0.998(95 \% \mathrm{Cl}, 0.994$ to 0.999$), \mathrm{p}<0.0001)$, as well as for all categories: bronchiectasis $(\mathrm{K}=0.812(95 \% \mathrm{Cl}$, 0.5964 to 1.028$), \mathrm{p}<0.0001$ ), mucus plugging ( $\mathrm{k}=0.888$ (95\% $\mathrm{Cl}, 0.674$ to 1.102$) \mathrm{p}<0.0001)$, centrilobular opacities $(\mathrm{K}=0.856$ ( $95 \% \mathrm{Cl}, 0.613$ to 1.099$) ; \mathrm{p}<0.0001)$, consolidation $(\mathrm{k}=1.0$; ( $95 \% \mathrm{Cl}, 1.0) ; \mathrm{p}<0.0001)$, sacculations ( $\mathrm{K}=$ not applicable), air trapping ( $\mathrm{k}=0.934 ;(95 \% \mathrm{Cl}, 0.808$ to 1.058$) \mathrm{p}<0.0001)$. The inter-reader correlation was also excellent $(\mathrm{K}=0.876-1.000$ for categorical values and MR-CF score $(\mathrm{ICC}=0.996(95 \% \mathrm{Cl}, 0.991$ to 0.999) $\mathrm{p}<0.0001$ for overall MR-CF-S).

\section{Discussion}

This study demonstrates differences in the severity and distribution of pulmonary pathologic manifestations in CF patients depending on their pancreatic function. Between the two groups controlled for pulmonary function (plus other variables), MRI detected a greater extent of pulmonary impairment amongst patients with pancreatic insufficiency; bronchiectasis and air trapping were the primary types of pathology accounting for MR-CF-S differences.

The challenges in obtaining standardized chest imaging for children (i. e., low radiation exposure, negligible artifacts and consistent lung volumes) have recently been overcome with improvements in MRI techniques [13, 16-18]. MRI is a radiation-free technique and can provide functional quantification of air trapping and lung perfusion with non-static imaging techniques. The benefits within pediatric radiology are obvious but are not limited to this sector, especially since high cumulative radiation dose of repetitive $\mathrm{CT}$ imaging and interventional procedures is known to increase the risk of malignancy $[19,20]$. MRI is sensitive with regard to detecting early structural lung changes and disease progression and monitoring therapy response in CF [9]. As a result, scoring systems for the quantification of lung disease have been established for CF patients similarly to CT [21] and can predict the life-limiting destruction of lung tissue [15]. To date, there are multiple CF MRI protocols across the world designed around a broad variety of user-radiologist's experience as well as an array of MR scanners. Wielputz et al. have recently shown the feasibility of a standardized pulmonary MRI protocol as an outcome measure of CF disease in a multi-center setting [22]. Thereby, infants and preschool-aged children (mean age of $3.2 \pm 1.5$ years) were sedated with chloral hydrate, and intravenously injected contrast media was used for lung perfusion imaging. However, the sedation of children at a young age carries risks that need to be consid- 


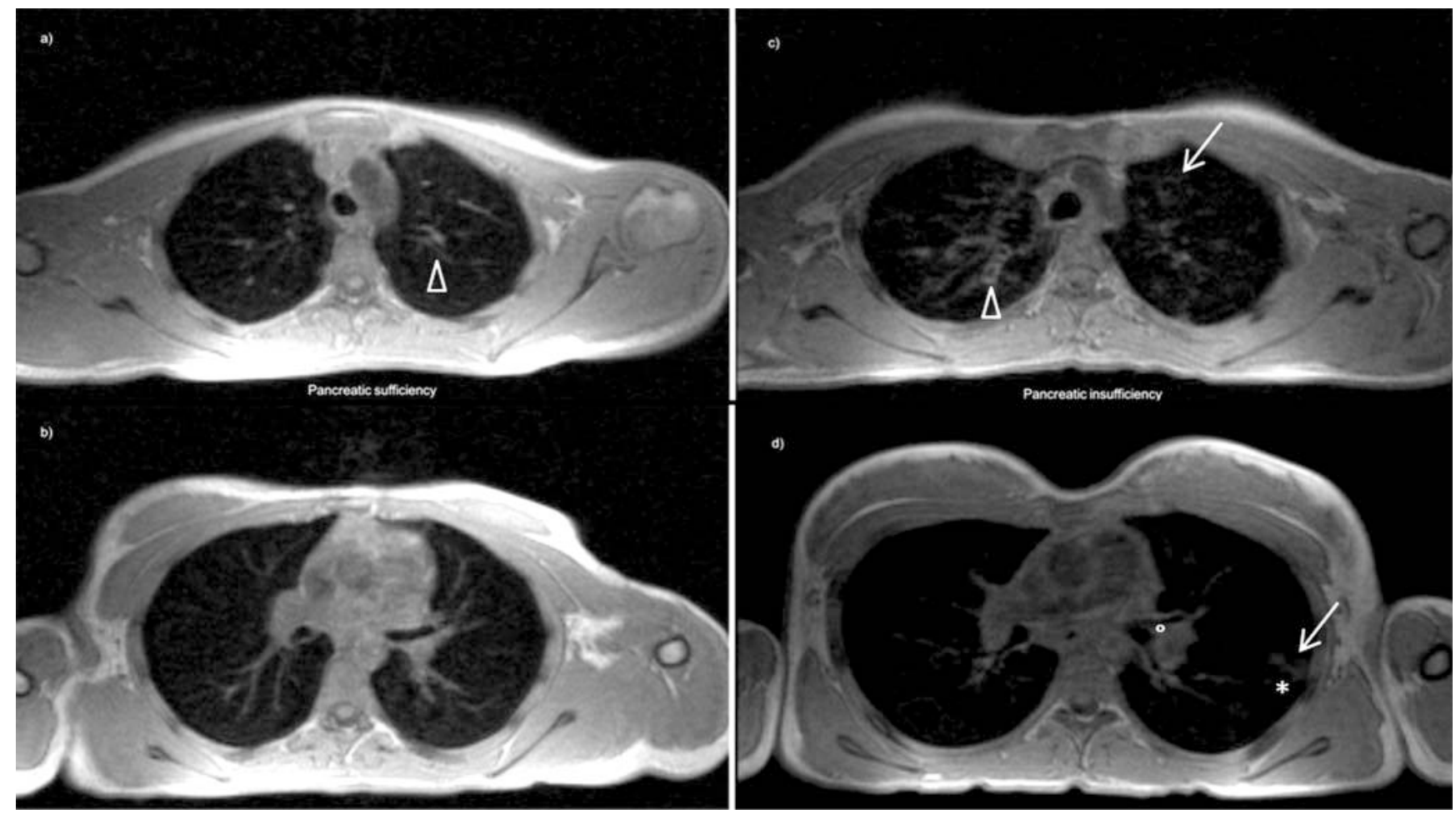

- Fig. 2 Images of two 16-year-old female patients with cystic fibrosis and similar results in pulmonary function testing. Transverse 3D gradient echo sequences in breath-hold show clear differences in lung pathology depending on the pancreatic status. Images $\mathbf{a}$ and $\mathbf{b}$ of the patient with pancreatic sufficiency ( $\mathrm{FeV}_{1} 98 \%$; BMl $17.7 \mathrm{~kg} / \mathrm{m}^{2}$ ) show mild bronchiectasis (arrow head), whereas the CF patient with pancreatic insufficiency ( $\mathrm{FeV}_{1} 96 \% ; \mathrm{BMI} 16.5 \mathrm{~kg} / \mathrm{m}^{2}$ ) in $\mathbf{c}$ and $\mathbf{d}$ shows severe bronchiectasis/peribronchial wall thickening (arrow head) and centrilobular opacities (arrow) with beginning consolidation $\left({ }^{*}\right)$ and hilar lymphadenopathy $\left({ }^{\circ}\right)$. Both patients showed chronic bacterization with staphylococcus aureus, as well as pseudomonas aeruginosa for the patient with pancreatic insufficiency.

- Abb. 2 MRT-Bilder zweier 16-jähriger Patientinnen mit CF und vergleichbaren Werten der Lungenfunktionstests. Die transversale 3D-Gradientenecho-Sequenz in Atemstopp zeigt eine deutlich unterschiedliche Ausprägung der strukturellen Lungengerüstveränderungen in Abhängigkeit der Pankreasfunktion. Bild a und $\mathbf{b}$ der pankreassuffizienten CF-Patientin ( $\mathrm{FeV}_{1} 98 \%$; BMI 17,7 kg/m²) zeigt mild ausgeprägte Bronchiektasien (Pfeilkopf), wohingegen die CF-Patientin mit insuffizienter Pankreasfunktion ( $F e V_{1} 96 \%$; BMl $\left.16,5 \mathrm{~kg} / \mathrm{m}^{2}\right)$ in c und d deutlich ausgeprägtere Lungengerüstveränderungen zeigt, wie Bronchiektasien, verdickte Peribronchialwände (Pfeilkopf) und zentrilobuläre Opazitäten (Pfeil) mit beginnender Konsolidierung $\left({ }^{*}\right)$ und hilärer Lymphadenopathie $\left({ }^{\circ}\right)$. Beide Patientinnen zeigten eine chronische bakterielle Besiedelung mit Staphylococcus aureus, die pankreasinsuffiziente Patientin zusätzlich auch mit Pseudomonas aeruginosa.

ered. Also, the use of MR contrast media (contraindicated in patients with impaired renal function) and the controversy of contrast deposition in the brain remains uncertain [29]. Our standardized CF MRI protocol, without the need for contrast media or sedation, has been shown to reliably capture both morphological and functional (submaximal inspiration and expiration) MRI sequences [12, 13]. However, imaging of young children without the use of sedation is challenging, so that an introduction to the MR scanner with playful examination scenarios, parental guidance/presence during the exam and good collaboration with medical personnel is crucial. The youngest patient included in this study was 6 years of age. In the clinical routine patients as young as 4 years old are undergoing MRI without sedation at our institute.

To our knowledge, this is the first study to depict differences in CF lung impairment between matched patients of differing pancreatic status using MRI. CF patients with PI showed significantly more severe characteristic structural pulmonary changes, such as bronchiectasis and air trapping, accounting for higher scores in the MR-CF-S when compared to PS-CF patients. Similarly, severe lung impairment has been described for PI-CF patients in contrast to PS-CF using CT [23-27]. Simanovsky et al. first used a modified scoring system (Brody CT score) and additionally described significant differences in the alteration distribution (with PI-CF being affected in the upper lung lobes whereas PS-PI showed more equally distributed pathologies) [24]. However, we cannot confirm significant differences in the distribution of pathological pulmonary changes depending on pancreatic status; PS-CF patients showed significantly more affected upper lung areas, concordant to the PI-CF patient group. This may be due to a less severely affected, young patient cohort.

Small airway disease can be monitored either functionally (by spirometry or multiple breath washout techniques) or anatomically by imaging. SLD on MRI is typically identifiable prior to functional changes $[28,29]$. Collectively these findings, especially the milder appearance of pulmonary structural changes in CF-PS patients, suggest that pancreatic function should be considered when determining disease severity and estimating course of progression. 

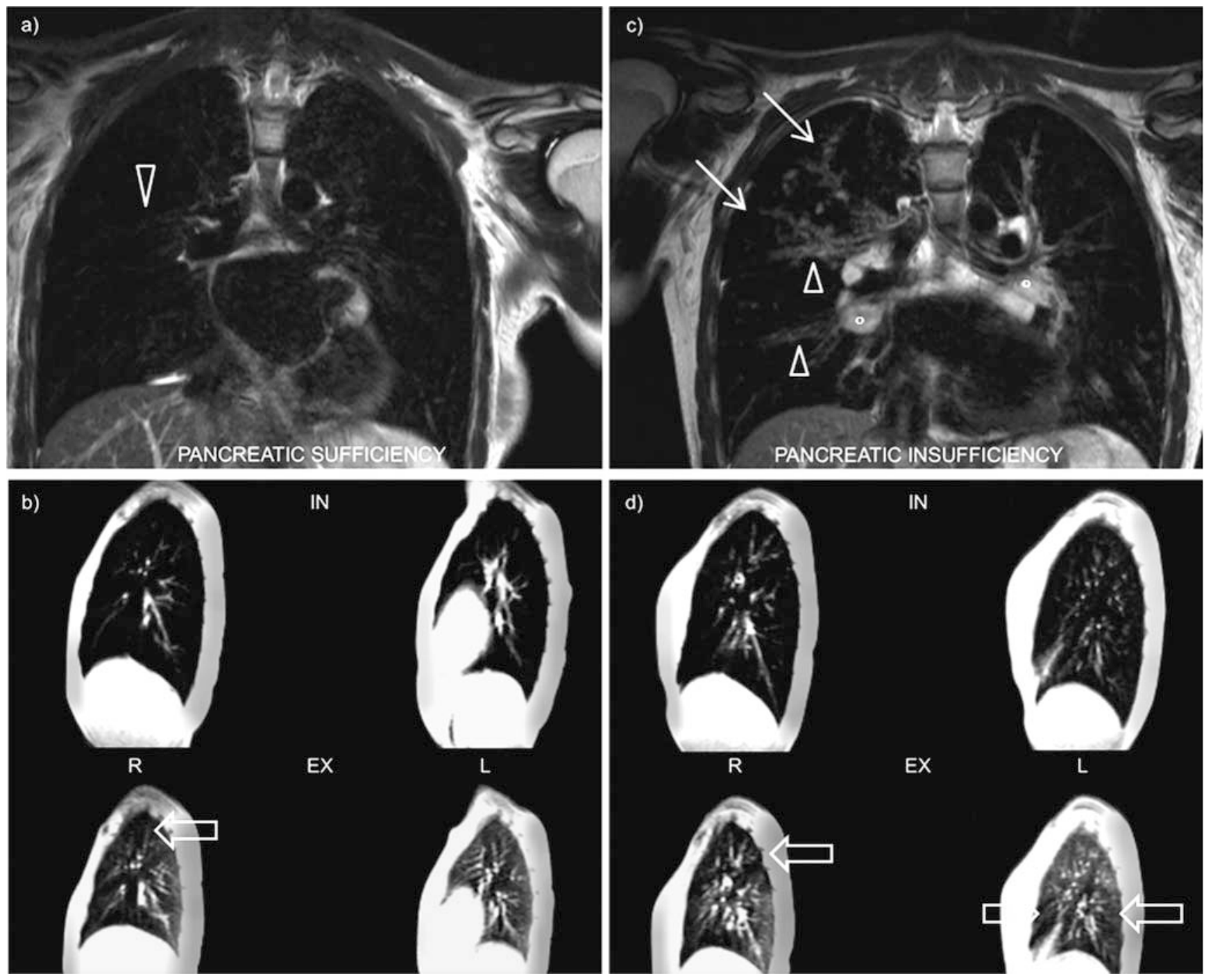

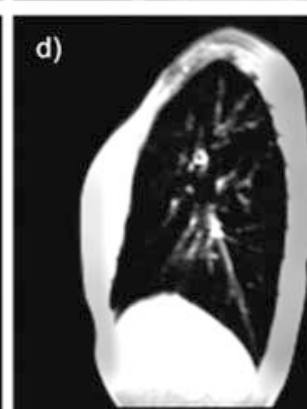

$\mathbf{R}$

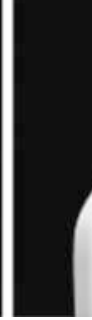

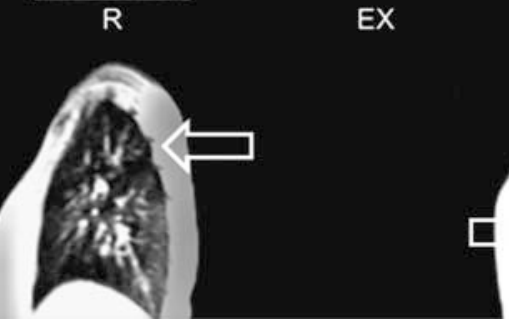

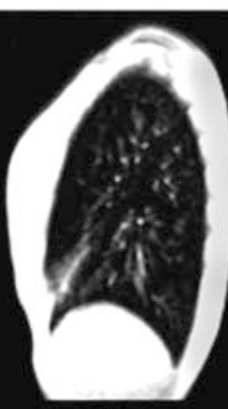

L

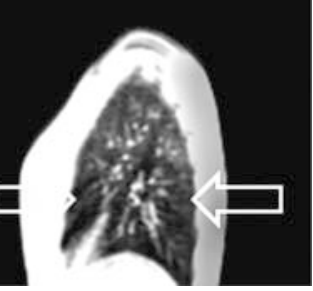

- Fig. 3 Coronal T2w turbo spin echo, as well as functional imaging with a sagittal proton-density-weighted 2D GRE sequence show different degrees of structural pulmonary changes in two patients with differing pancreatic function. Pictures $\mathbf{a}$ and $\mathbf{b}$ of a CF patient with sufficient pancreatic status show minor pulmonary changes with regional air trapping (translucent block arrow) in the right upper lung lobe on the submaximal expiration images (lower row). To the left, image c shows clearly marked bronchiectasis (arrow head) in the upper lobes, as well as the middle lobe, minor centrilobular opacity (arrow) in the right upper lobe and hilar lymphadenopathy $\left({ }^{\circ}\right.$ ). Images $\mathbf{d}$ show regional air trapping of the right upper lobe, as well as middle lobe and the left lower lobe (translucent arrow).

- Abb. 3 Morphologische koronale T2-gewichtete Turbo-Spin-Echo- und funktionelle sagittale protonengewichtete 2D-Gradientenecho-Sequenzen zeigen deutlich differente Ausprägungen der strukturellen pulmonalen Veränderungen zweier CF-Patienten in Abhängigkeit der Pankreasfunktion. Bild $\mathbf{a}$ und $\mathbf{b}$ eines pankreassuffizienten Patienten zeigen milde pulmonale Veränderungen mit regionaler Überblähung/Air Trapping (transparenter Pfeilkopf) im rechten Lungenoberlappen in submaximaler Atemlage (untere Reihe). Linksstehendes Bild c zeigt deutliche Bronchiektasien (Pfeilkopf) in den Oberlappen und im Mittellappen, milde zentrilobuläre Opazitäten (Pfeil) im rechten Oberlappen sowie eine hiläre Lymphadenopathie $\left({ }^{\circ}\right)$. Bild d zeigt regionale Überblähungsareale im rechten Oberlappen, Mittellappen und im linken Lungenunterlappen (transparenter Pfeil).

The combination of CF newborn screening and early imaging of clinically pre-symptomatic patients is an opportunity to delay and possibly prevent irreversible pulmonary changes and disease progression by early patient-based individualized therapeutic interventions [30].

Some limitations of this study need to be addressed. [1] The number of PS-CF patients was limited, resulting in a small and young-aged study cohort and thus in earlier disease stages and without pathological findings typical of later CF (such as saccula- tions). [1] The lack of direct technical comparison of MRI with CT, ideally with expiratory imaging and scoring is limited owing to radiation exposure. However, this is not reasonable in a pediatric study population. [1] Areas with air trapping and mosaic pattern are not explicitly due to inadequate ventilation but can additionally be caused by declined perfusion due to the Euler-Liljestrand mechanism [31]. [1] Lastly, we did not include newer, promising MRI techniques like ultra-short echo time sequences at submillimeter resolution. 
- Table 3 CF-MR score distribution depending on the pancreatic status.

- Tab.3 Verteilung der CF-MR-Score-Punkte in Abhängigkeit der Pankreasfunktion.

\begin{tabular}{|c|c|c|c|}
\hline lung structure & PS-CF & $\mathrm{PI}-\mathrm{CF}$ & P-value \\
\hline both lungs & $3(0-4.25)$ & $5.5(3.75-14.5)$ & $0.0243^{*}$ \\
\hline bronchiectasis/peribronchial wall thickening & $0.5(0-1.25)$ & $3(1.75-6.25)$ & $0.0042^{*}$ \\
\hline mucus plugging & $0(0-0.25)$ & $0(0-2.0)$ & 0.2244 \\
\hline centrilobular opacities & $0(0-0)$ & $0(0-1.25)$ & 0.2792 \\
\hline sacculations & $0(0-0)$ & $0(0-0)$ & 1.000 \\
\hline consolidations & $0(0-1.0)$ & $0.5(0-1.0)$ & 0.4345 \\
\hline air trapping & $0(0-1.25)$ & $2.5(0.75-4.0)$ & $0.0304^{*}$ \\
\hline upper lung area ${ }^{\circ}$ & $0(0-3.25)$ & $3.5(1.75-10.25)$ & $0.0247^{*}$ \\
\hline lower lung area & $0(0-1.5)$ & $2.0(1.0-4.25)$ & $0.0196^{*}$ \\
\hline \multicolumn{4}{|c|}{$\begin{array}{l}\text { Data are presented as median ( } 25-75 \text { quantiles). Cystic fibrosis (CF) patients with sufficient pancreatic function (PS) and insufficient pancreatic function } \\
\text { (PI). }{ }^{\circ} \text { Upper area included the upper, middle lung lobe and lingula. } \\
\text { Angaben als Median ( } 25-75 . \text { Quartile); Zystische-Fibrose (CF) -Patienten mit suffizienter (PS) und insuffizienter Pankreasfunktion (PI). }{ }^{\circ} \text { Oberfelder bein- } \\
\text { haltet die Oberlappen, den rechten Mittellappen bzw. das Lingula-Segment. }\end{array}$} \\
\hline
\end{tabular}

We have demonstrated that the degree of lung pathology on MRI correlates to the pancreatic status in patients with $\mathrm{CF}$, and $\mathrm{PI}$ was associated with more severe pulmonary changes, especially bronchiectasis and air trapping. The latter is reversible. From a radiologist's point of view, the pancreatic status of CF patients should be considered in disease monitoring, planning of targeted individualized therapy and assessment of its effectiveness. Thus, the pancreatic status of CF patients should be assessed in a timely manner to help remedy reversible pulmonary changes.

\section{CLINICAL RELEVANCE}

- Radiation-free pulmonary MRI can be used for morphological and functional lung imaging

- The degree of lung pathology correlates to the pancreatic status in CF patients

- The pancreatic status should be considered in therapy planning

\section{Conflict of Interest}

The authors declare that they have no conflict of interest.

\section{References}

[1] Lugo-Olivieri CH, Soyer PA, Fishman EK. Cystic fibrosis: spectrum of thoracic and abdominal CT findings in the adult patient. Clin Imaging 1998; 22: 346-354. doi:S0899-7071(98)00031-X [pii]

[2] [Anonym]. In, World Health Organization Genes and Human Disease. http:// www.who.int/genomics/public/geneticdiseases/en/index2.html - CF
[3] Kerem E, Reisman J, Corey $M$ et al. Prediction of mortality in patients with cystic fibrosis. N Engl J Med 1992; 326: 1187-1191. doi:10.1056/ nejm199204303261804

[4] Elborn JS. Cystic fibrosis. Lancet 2016; 388: 2519-2531. doi:10.1016/ S0140-6736(16)00576-6

[5] Quinton PM. Cystic fibrosis: impaired bicarbonate secretion and mucoviscidosis. Lancet 2008; 372: 415-417. doi:10.1016/S01406736(08)61162-9

[6] Brody AS, Tiddens HA, Castile RG et al. Computed tomography in the evaluation of cystic fibrosis lung disease. Am J Respir Crit Care Med 2005; 172: 1246-1252. doi:10.1164/rccm.200503-401PP

[7] de Gracia J, Mata F, Alvarez A et al. Genotype-phenotype correlation for pulmonary function in cystic fibrosis. Thorax 2005; 60: 558-563. doi:10.1136/thx.2004.031153

[8] de Jong PA, Lindblad A, Rubin L et al. Progression of lung disease on computed tomography and pulmonary function tests in children and adults with cystic fibrosis. Thorax 2006; 61: 80-85. doi:10.1136/ thx.2005.045146

[9] Wielputz MO, Puderbach M, Kopp-Schneider A et al. Magnetic resonance imaging detects changes in structure and perfusion, and response to therapy in early cystic fibrosis lung disease. Am J Respir Crit Care Med 2014; 189: 956-965. doi:10.1164/rccm.201309-16590C

[10] Carpio C, Albi G, Rayon-Aledo JC et al. Changes in structural lung disease in cystic fibrosis children over 4 years as evaluated by high-resolution computed tomography. Eur Radiol 2015; 25: 3577-3585. doi:10.1007| s00330-015-3782-4

[11] Tiddens HA, Rosenow T. What did we learn from two decades of chest computed tomography in cystic fibrosis? Pediatr Radiol 2014; 44: 14901495. doi:10.1007/s00247-014-2964-6

[12] Tiddens HA, Stick SM, Davis S. Multi-modality monitoring of cystic fibrosis lung disease: the role of chest computed tomography. Paediatr Respir Rev 2014; 15: 92-97. doi:10.1016/j.prrv.2013.05.003

[13] Kolodziej M, de Veer M], Cholewa M et al. Lung function imaging methods in Cystic Fibrosis pulmonary disease. Respir Res 2017; 18: 96. doi:10.1186/s12931-017-0578-x 
[14] Teufel M, Ketelsen D, Fleischer S et al. Comparison between high-resolution CT and MRI using a very short echo time in patients with cystic fibrosis with extra focus on mosaic attenuation. Respiration 2013; 86: 302-311. doi:10.1159/000343085

[15] Schaefer JF, Hector A, Schmidt K et al. A semiquantitative MRI-Score can predict loss of lung function in patients with cystic fibrosis: Preliminary results. Eur Radiol 2017. doi:10.1007/s00330-017-4870-4

[16] Dournes G, Menut F, Macey J et al. Lung morphology assessment of cystic fibrosis using MRI with ultra-short echo time at submillimeter spatial resolution. Eur Radiol 2016; 26: 3811-3820. doi:10.1007/s00330-0164218-5

[17] Dournes G, Grodzki D, Macey J et al. Quiet Submillimeter MR Imaging of the Lung Is Feasible with a PETRA Sequence at 1.5 T. Radiology 2016; 279: 328. doi:10.1148/radiol.2016164006

[18] Altes TA, Meyer CH, Mata JF et al. Hyperpolarized helium-3 magnetic resonance lung imaging of non-sedated infants and young children: a proof-of-concept study. Clin Imaging 2017; 45: 105-110. doi:10.1016/ j.clinimag.2017.04.004

[19] Kuo W, Ciet P, Tiddens HA et al. Monitoring cystic fibrosis lung disease by computed tomography. Radiation risk in perspective. Am J Respir Crit Care Med 2014; 189: 1328-1336. doi:10.1164/rccm.201311-2099Cl

[20] Pearce MS, Salotti JA, Little MP et al. Radiation exposure from CT scans in childhood and subsequent risk of leukaemia and brain tumours: a retrospective cohort study. Lancet 2012; 380: 499-505. doi:10.1016/ S0140-6736(12)60815-0

[21] Calder AD, Bush A, Brody AS et al. Scoring of chest CT in children with cystic fibrosis: state of the art. Pediatr Radiol 2014; 44: 1496-1506. doi:10.1007/s00247-013-2867-y

[22] Wielputz MO, von Stackelberg O, Stahl M et al. Multicentre standardisation of chest MRI as radiation-free outcome measure of lung disease in young children with cystic fibrosis. J Cyst Fibros 2018; 17: 518-527. doi:10.1016/j.jcf.2018.05.003
[23] Schaedel C, de Monestrol I, Hjelte L et al. Predictors of deterioration of lung function in cystic fibrosis. Pediatr Pulmonol 2002; 33: 483-491. doi:10.1002/ppul.10100

[24] Simanovsky N, Cohen-Cymberknoh M, Shoseyov D et al. Differences in the pattern of structural abnormalities on CT scan in patients with cystic fibrosis and pancreatic sufficiency or insufficiency. Chest 2013; 144: 208-214. doi:S0012-3692(13)60469-9 [pii] 10.1378/chest.12-1226

[25] Lebenthal E, Rolston DD, Holsclaw DS et al. Enzyme therapy for pancreatic insufficiency: present status and future needs. Pancreas 1994; 9: 1-12

[26] Durno C, Corey M, Zielenski J et al. Genotype and phenotype correlations in patients with cystic fibrosis and pancreatitis. Gastroenterology 2002; 123: 1857-1864. doi:10.1053/gast.2002.37042

[27] Zielenski ]. Genotype and phenotype in cystic fibrosis. Respiration 2000; 67: 117-133. doi:10.1159/000029497

[28] Brody AS, Klein JS, Molina PL et al. High-resolution computed tomography in young patients with cystic fibrosis: distribution of abnormalities and correlation with pulmonary function tests. J Pediatr 2004; 145: 3238. doi:10.1016/j.jpeds.2004.02.038

[29] Stahl M, Wielputz MO, Graeber SY et al. Comparison of Lung Clearance Index and Magnetic Resonance Imaging for Assessment of Lung Disease in Children with Cystic Fibrosis. Am J Respir Crit Care Med 2017; $195:$ 349-359. doi:10.1164/rccm.201604-08930C

[30] Mall MA, Stahl M, Graeber SY et al. Early detection and sensitive monitoring of CF lung disease: Prospects of improved and safer imaging. Pediatr Pulmonol 2016; 51: S49-S60. doi:10.1002/ppul.23537

[31] Kraemer R, Blum A, Schibler A et al. Ventilation inhomogeneities in relation to standard lung function in patients with cystic fibrosis. Am J Respir Crit Care Med 2005; 171: 371-378. doi:200407-9480C [pii] 10.1164/ rccm.200407-9480C 